\title{
NEUROTOXICITY EVALUATION OF FENTANYL ANALOGS IN RATS
}

VUČKOVIĆ SONJA*, SAVIĆ VUJOVIĆ KATARINA*, IVANOVIĆ M**, DOŠEN-MIĆOVIĆ LJILJANA**, TODOROVIĆ Z*, VUČETIĆ Č ${ }^{\star},{ }^{\star \star \star}$, PROSTRAN M* and PROSTRAN MILICA*

\author{
*University of Belgrade, Faculty of Medicine, Serbia \\ **University of Belgrade, Faculty of Chemistry, Serbia \\ ${ }^{* * *}$ Clinical Center of Serbia, Institute for Orthopaedic Surgery and Traumatology, Serbia
}

(Received 2nd August 2011)

This study aimed at evaluating the neurotoxicity of fentanyl analogs: ( \pm )-cis-3-carbomethoxy fentanyl (C) and ( \pm )-trans-3carbomethoxy fentanyl $(T)$ in rats. $C$ and $T$ are less potent (2.4-3.1 and 8.4-12.3 times, respectively) than fentanyl (F) in producing both antinociception and morphine-like neurotoxic effects: loss of pinna reflex, Straub tail, impairment of motor coordination, catalepsy, loss of corneal reflex and loss of righting reflex. All of the effects tested were dose-dependent and they were abolished by pretreatment with naloxone, nonselective antagonist of opioid receptors, indicating that they are mediated via opioid receptors. Further, F, C and T exhibited similar relative potencies in producing all tested effects, indicating that similar receptors are involved in producing antinociceptive and neurotoxic effects, most probably of $\mu$ type. By using equiantinociceptive doses, $C$ and $T$ produced significantly shorter duration of both antinociception and neurotoxicity than F. No significant differences between therapeutic indices for $F, C$ and $T$ were found, indicating that these compounds are equally safe and tolerable in respect to the neurotoxic effects tested. Neurotoxicity testing presented in this paper may be useful in studying the structure-activity relationship of opioid congeners.

Key words: analog, fentanyl, neurotoxicity, rats

\section{INTRODUCTION}

Fentanyl (Fig. 1A) belongs to 4-anilidopiperidine class of synthetic opioid analgesics (Janssen et al., 1996). It is a strong opioid analgesic with widespread use in the treatment of moderate to severe pain. However, the clinical use of the fentanyl is limited by serious central nervous system side effects such as respiratory depression, sedation, nausea, muscle rigidity, and after prolonged use, tolerance and addiction (Geppetti and Benemei, 2009). Like morphine and most other currently available strong opioid analgesics, fentanyl exerts analgesic and adverse effects primarily through the opioid $\mu$ receptors (Schumacher et al., 2007). 
The most common approach in searching for novel drugs is structural modification of the well known compounds (Mićović et al., 2000; Ivanović et al., 2004a; Ivanović et al., 2004b; Vučković et al., 2009). Among the important properties of the opioids that can be altered by structural modification are their affinities for various types of opioid receptors, activities as agonists versus antagonists, lipid solubilities, and their susceptibility/resistance to metabolic breakdown (Feldman et al., 1991; Scholz et al., 1996; Ananthan, 2006).

Carfentanil (Fig. 1B) is 20-30 times more potent than fentanyl and is used in veterinary medicine for immobilization of wild animals (Van Daele, 1976; De Vos, 1978). In previous work (Mićović et al., 1998; Vučković et al., 2000), the regioisomer of carfentanyl, 3-carbomethoxy fentanyl (Fig. 1C and 1D), or "isocarfentanil" was prepared and tested for analgesic activity in rats. It was found that ( \pm )-cis-3-carbomethoxy fentanyl (Fig. 1C) and ( \pm )-trans-3-carbomethoxy fentanyl (Fig. 1D) were about 2 and 10 times less potent than fentanyl, respectively, but their tolerability and safety compared with fentanyl remained unexplored. This study is aimed at evaluating the relative tolerability and safety of $( \pm)$-cis and $( \pm)$ trans-3-carbomethoxy fentanyl, by using tests for assesing morphine-like neurotoxicity in rats, such as loss of pinna reflex, impairment of motor coordination, Straub tail (tail in an erect position), catalepsy (muscular rigidity and immobility), loss of corneal reflex and loss of righting reflex. In addition, in regard to the neurotoxic effects, structure-activity relationship (SAR) of ( \pm )-cis and ( \pm )trans-3-carbomethoxy fentanyl was to be established.<smiles>CCC(=O)N(c1ccccc1)C1CCN(CCc2ccccc2)CC1</smiles>

Figure 1. Fentanyl (A), carfentanil (B), ( \pm )-cis-3-carbomethoxy fentanyl $(C)$ and

\section{MATERIALS AND METHODS}

\section{Animals}

Male Wistar rats (200-250 g) obtained from Military Farm (Belgrade, Serbia) were used. All experiments were approved by the Institutional Animal Ethics Committee which operates in accordance with Revised Guide for the Care and Use of Laboratory Animals (NIH Guide, Volume 25, Number 28, 1996). The animals were housed in groups of 4 in plexiglass cages $(36.5 \times 21 \times 14 \mathrm{~cm})$ under standard conditions: temperature of $22^{\circ} \mathrm{C} \pm 1^{\circ} \mathrm{C}$, and a $12 / 12 \mathrm{~h}$ light/dark cycle with lights on at $08.00 \mathrm{~h}$. Food pallets and tap water were available ad libitum, except during the experimental procedure. Prior to each experiment the animals 
were habituated to handling and experimental procedures for at least three consecutive days. Experiments were done in a sound-proofed, diffusely illuminated room maintained at a temperature of $22 \pm 1^{\circ} \mathrm{C}$. They were performed at the same time of the day between 9:00 and 13:00 $\mathrm{h}$ to avoid diurnal variation in behavioral tests. The animals were unrestrained during all experimental procedures, except antinociception testing. Experimental groups consisted of 6-8 rats. Each animal was tested only once and was killed with an intraperitoneal injection of sodium thiopental.

\section{Antinociception testing}

In the first set of experiments, antinociceptive activity was determined by tailimmersion test (Janssen et al., 1963). In brief, the rat was placed in a hemicylindrical plexiglass cage with its tail hanging freely outside the cage. The distal $5 \mathrm{~cm}$ of the tail was immersed in a warm water bath $\left(55 \pm 0.5^{\circ} \mathrm{C}\right)$ and the time for tail-withdrawal was measured as a response latency. In order to minimize tissue damage by repeated testing, a cut-off time of $6 \mathrm{~s}$ was adopted. This means that the maximal duration of a single exposure of rat tail to hot water was $6 \mathrm{sec}$. Predrug response latency was obtained $5 \mathrm{~min}$ before i.p. drug (or saline solution in the control group) administration. Postdrug response latency was measured after intraperitoneal (i.p.) administration of test compound (or saline solution in the control group) at 5, 10, 15, 20, 40, 60, 90 etc. min. The data are expressed quantally as the number of animals in which the antinociception was observed versus total number of animals receiving the same treatment. For antinociception, the following criterion was used: an antinociceptive effect was said to have occurred if postdrug response latency was $\geq 6 \mathrm{~s}$.

\section{Neurotoxicity testing}

In the second set of experiments, toxic effects were tested in the following order: loss of pinna reflex, loss of corneal reflex, tail stiffness (Straub tail), catalepsy, impairment of motor coordination and loss of righting reflex in each single rat. Experimental groups consisted of 6-8 rats. The data are expressed quantally as the number of animals in which the effect was observed versus total number of animals receiving the same treatment.

Testing was performed once before and at 5, 20, 40, 60, 90 etc. min after i.p. drug (or saline solution in the control group) injection by two observers unaware of the pharmacological treatment. Tail stiffness ("Straub tail") was assessed by observation, as well as touching the tail (Benthuysen et al., 1986). The pinna reflex was tested by touching the pinna with a pencil tip. (Meert et al., 1988). The corneal reflex was tested by touching the cornea with a small peace of cotton (Meert et al., 1988). Catalepsy was defined as the failure of the animal to move within $60 \mathrm{~s}$ from a position in which the forepaws and hind paws were placed on bars $10 \mathrm{~cm}$ from the floor (Klemm, 1989; Vučković et al., 1998). The righting reflex was measured by placing the animal onto its back and measuring how long it took to regain an upright position. The righting reflex was considered absent when all four limbs remained off the table surface for at least $30 \mathrm{~s}$ (Yang et al., 1992; Ivanović et al., 1995). Impairment of motor coordination was defined as the inability of the rat to 
descend in a coordinated fashion a 60-degree-inclined wire mesh ramp (Yaksh et al., 1986).

\section{Drugs Administration}

Fentanyl citrate (ICN Yugoslavia, Belgrade, Serbia) and ( \pm )-cis and $( \pm)$ trans-3-carbomethoxy fentanyl oxalate were dissolved in saline and injected intraperitoneally at a final volume of $2 \mathrm{~mL} / \mathrm{kg}$. Both ( \pm )-cis and ( \pm )-trans-3carbomethoxy fentanyl (Faculty of Chemistry, University of Belgrade, Serbia) were examined as a racemic mixture. Doses of the drugs were calculated for the free base. Naloxone hydrochloride (Sigma Chemical Co. St. Louis, USA) was also dissolved in saline, and injected subcutaneously (s.c., $1 \mathrm{mg} / \mathrm{kg}$ ) in the back 10 min before the intraperitoneal (i.p.) injection of the test compound in the same volume. In order to test whether saline injection has any effect on nociception or toxic behavior, $2 \mathrm{~mL} / \mathrm{kg}$ of saline were administrated i.p. in a control group of rats.

\section{Statistical Analysis}

To permit direct comparison of different compounds and different effects, basic data for each animal were transformed to a quantal response (presence or absence of expected drug effect). For each effect and each dose maximum response obtained during time of measurement was used for evaluation. Then, computations were done according to the methods of Tallarida and Murray (1986).

\section{RESULTS}

Fentanyl (F; 0.0073-0.120 mg/kg; ip), ( \pm )cis 3-carbomethoxy fentanyl (C; 0.016-0.326 mg/kg; ip) and ( \pm )trans 3-carbomethoxy fentanyl (T; 0.08-1.22 mg/kg; i.p) produced dose-dependent increase in antinociception, loss of pinna reflex, impairment of motor coordination, Straub tail, catalepsy, loss of corneal reflex and loss of righting reflex (Fig. 2). For each effect tested, probit slopes for F, C and T are not significantly different ( $p>0.05$, test for parallelism).

The median effective doses for antinociception $\left(A D_{50}\right)$ and toxic effects $\left(\mathrm{TD}_{50}\right)$, and the relative potencies for $\mathrm{F}, \mathrm{C}$ and $\mathrm{T}$ are presented in Table 1. The median effective doses $\left(E D_{50}\right)$ for $C$ and $T$ are significantly higher $(p<0.05)$ in comparison with the corresponding doses for $F$ (Table 1), indicating that $C$ and $T$ are less potent than $\mathrm{F}$ in producing antinociceptive and toxic effects. Also, T was significantly less potent $(p<0.05)$ in producing all observed effects compared with $C$ (Table 1). The potency ratios indicate that $C\left(E D_{50}=0.024(0.017-0.034)\right)$ and $T$ $\left(E D_{50}=0.084(0.054-0.131)\right)$ are less potent analgesics (2.4 and 8.4 times, respectively), in comparison with $\mathrm{F}\left(\mathrm{ED}_{50}=0.010(0.007-0.014)\right)$. In regard to toxic effects, $C$ and $T$ are less potent (2.4-3.1 and 10.8-12.3 times, respectively) than $F$ (Table 1). $T$ is 3.5 and 3.6-5.1 times less potent than $C$ in inducing antinociception and toxicity, respectively (not shown).

Each of tested compounds, exhibited similar $(p>0.05)$ relative potencies in producing all tested effects (95\% confidence intervals overlap) (Table 1$)$. 

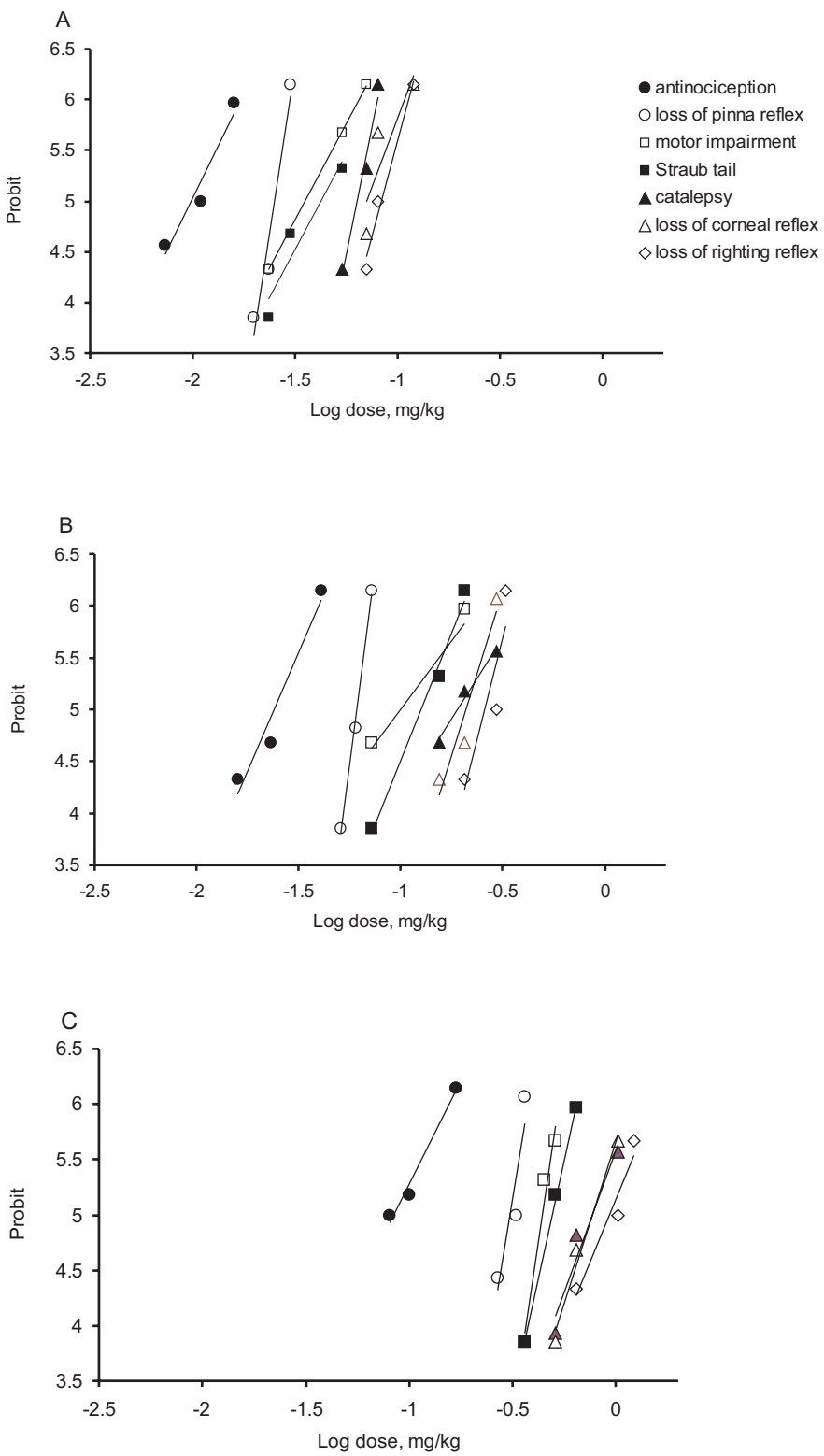

Figure 2. Log dose-probit curves for antinociception (tail-immersion test) and toxic effects for fentanyl (A), ( \pm )-cis-3-carbomethoxy fentanyl (B) and ( \pm )-trans-3-carbomethoxy fentanyl $(C)$ in rats. Doses of the compound tested are expressed in $\mathrm{mg} / \mathrm{kg}$. For each effect and each dose, the percentage of rats that respond to treatment is transformed to a probit value. Each point represents the results obtained from 6-8 rats 
Table 1. Median effective doses $\left(A D_{50}\right.$ and $\left.T D_{50}\right)$, correlation coefficient $(r)$, probit slopes and relative potencies with 95\% confidence limits $(95 \% \mathrm{CL})$ for fentanyl, ( \pm )-cis-3-carbomethoxy fentanyl and $( \pm)$-trans-3-carbomethoxy fentanyl in inducing antinociception, loss of pinna reflex, motor impairement, Straub tail, catalepsy, loss of corneal reflex, and loss of righting reflex in rats

\begin{tabular}{|c|c|c|c|c|}
\hline Effect & $\begin{array}{c}\mathrm{AD}_{50} \text { or } \mathrm{TD}_{50} \\
(95 \% \mathrm{CL}) \\
\end{array}$ & $r$ & $\begin{array}{l}\text { Probit slope } \\
(95 \% \mathrm{CL}) \\
\end{array}$ & $\begin{array}{c}\text { Relative potency } \\
(95 \% \mathrm{CL})\end{array}$ \\
\hline \multicolumn{5}{|c|}{ Fentanyl $(0,0073-0,12$ mg/kg) } \\
\hline Antinocicep. ${ }^{a}$ & $\begin{array}{c}0.010 \\
(0.007-0.014) \\
\end{array}$ & 0.968 & $\begin{array}{c}4.08 \\
(-9.3-17.5) \\
\end{array}$ & 1 \\
\hline Loss of pinna r. & $\begin{array}{c}0.025 \\
(0.021-0.030) \\
\end{array}$ & 0.981 & $\begin{array}{c}13.1 \\
(-20.1-46.4) \\
\end{array}$ & 1 \\
\hline Motor impair. & $\begin{array}{c}0.036 \\
(0.023-0.054) \\
\end{array}$ & 1.000 & $\begin{array}{c}3.8 \\
(3.0-4.5) \\
\end{array}$ & 1 \\
\hline Straub tail & $\begin{array}{c}0.043 \\
(0.030-0.060) \\
\end{array}$ & 0.957 & $\begin{array}{c}3.8 \\
(-10.1-18.6) \\
\end{array}$ & 1 \\
\hline Catalepsyb & $\begin{array}{c}0.064 \\
(0.054-0.074) \\
\end{array}$ & 0.983 & $\begin{array}{c}10.3 \\
(-13.8-34.3) \\
\end{array}$ & 1 \\
\hline Loss of corn. r. & $\begin{array}{c}0.071 \\
(0.053-0.095) \\
\end{array}$ & 0.871 & $\begin{array}{c}5.4 \\
(-33.3-44.1) \\
\end{array}$ & 1 \\
\hline Loss of right. $r^{c}{ }^{c}$ & $\begin{array}{c}0.084 \\
(0.068-0.100)\end{array}$ & 0.987 & $\begin{array}{c}7.5 \\
(-8.3-23.3) \\
\end{array}$ & 1 \\
\hline \multicolumn{5}{|c|}{ ( \pm )-cis-3-Carbomethoxy fentanyl (0.016-0.326 mg/kg) } \\
\hline Antinocicep. & $\begin{array}{c}0.024 \\
(0.017-0.034)\end{array}$ & 0.977 & $\begin{array}{c}4.6 \\
(-8.1-17.3)\end{array}$ & $\begin{array}{c}0.408^{\star} \\
(0.247-0.676)\end{array}$ \\
\hline Loss of pinna $r$. & $\begin{array}{c}0.061 \\
(0.052-0.071) \\
\end{array}$ & 0.999 & $\begin{array}{c}15.6 \\
(5.3-25.5) \\
\end{array}$ & $\begin{array}{c}0.412^{\star} \\
(0.328-0.518) \\
\end{array}$ \\
\hline Motor impair. & $\begin{array}{c}0.099 \\
(0.060-0.166) \\
\end{array}$ & 0.962 & $\begin{array}{c}2.7 \\
(-6.9-12.3) \\
\end{array}$ & $\begin{array}{c}0.357^{*} \\
(0.184-0.693) \\
\end{array}$ \\
\hline Straub tail & $\begin{array}{c}0.125 \\
(0.080-0.197) \\
\end{array}$ & 0.995 & $\begin{array}{c}5.0 \\
(-1.6-11.6) \\
\end{array}$ & $\begin{array}{c}0.339^{\star} \\
(0.192-0.599) \\
\end{array}$ \\
\hline Catalepsyb & $\begin{array}{c}0.189 \\
(0.123-0.291) \\
\end{array}$ & 0.988 & $\begin{array}{c}3.1 \\
(-3.0-9.3) \\
\end{array}$ & $\begin{array}{c}0.336^{*} \\
(0.213-0.529) \\
\end{array}$ \\
\hline Loss of corn. r. & $\begin{array}{c}0.208 \\
(0.169-0.256) \\
\end{array}$ & 0.969 & $\begin{array}{c}6.4 \\
(-14.3-26.9) \\
\end{array}$ & $\begin{array}{c}0.342^{\star} \\
(0.240-0.488) \\
\end{array}$ \\
\hline Loss of right. $\mathrm{rc}^{\mathrm{c}}$ & $\begin{array}{c}0.257 \\
(0.217-0.303) \\
\end{array}$ & 0.885 & $\begin{array}{c}7.7 \\
(-43.8-59.2) \\
\end{array}$ & $\begin{array}{c}0.327^{\star} \\
(0.250-0.426) \\
\end{array}$ \\
\hline \multicolumn{5}{|c|}{ ( \pm )-trans-3-Carbomethoxy fentanyl (0.08-1.22 mg/kg) } \\
\hline Antinocicep. ${ }^{a}$ & $\begin{array}{c}0.084 \\
(0.054-0.131)\end{array}$ & 0.988 & $\begin{array}{c}3.6 \\
(-3.5-10.7)\end{array}$ & $\begin{array}{c}0.117^{\star} \\
(0.066-0.209)\end{array}$ \\
\hline
\end{tabular}


Acta Veterinaria (Beograd), Vol. 62, No. 1, 3-15, 2012.

Vučković Sonja et al.: Neurotoxicity evaluation of fentanyl analogs in rats

cont. Table 1.

\begin{tabular}{|l|c|c|c|c|}
\hline Loss of pinna r. & $\begin{array}{c}0.308 \\
(0.274-0.346)\end{array}$ & 0.924 & $11.6(-49.3-72.4)$ & $\begin{array}{c}0.082^{*} \\
(0.067-0.100)\end{array}$ \\
\hline Motor impair. & $\begin{array}{c}0.441 \\
(0.389-0.499)\end{array}$ & 0.974 & $12.5(-24.0-48.9)$ & $\begin{array}{c}0.081^{*} \\
(0.052-0.125)\end{array}$ \\
\hline Straub tail & $\begin{array}{c}0.513 \\
(0.404-0.651)\end{array}$ & 0.982 & $7.0(-10.2-24.3)$ & $\begin{array}{c}0.083^{*} \\
(0.055-0.126)\end{array}$ \\
\hline Catalepsyb & $\begin{array}{c}0.767 \\
(0.587-1.003)\end{array}$ & 0.971 & $5.2(-11.1-21.5)$ & $\begin{array}{c}0.083^{*} \\
(0.061-0.113)\end{array}$ \\
\hline Loss of corn. r. & $\begin{array}{c}0.768 \\
(0.587-1.006)\end{array}$ & 0.991 & $5.9(-4.5-16.9)$ & $\begin{array}{c}0.093^{*} \\
(0.062-0.138)\end{array}$ \\
\hline Loss of right. $r^{c}$. & $\begin{array}{c}0.927 \\
(0.696-1.235)\end{array}$ & 0.970 & $4.6(-10.1-19.2)$ & $\begin{array}{c}0.091^{*} \\
(0.064-0.129)\end{array}$ \\
\hline
\end{tabular}

$A D_{50}=$ median effective doses $\left(E D_{50}\right)$ in inducing antinociception. $T_{50}=$ median effective doses $\left(E D_{50}\right)$ in inducing toxic effects. Median effective doses for each effect and each compound was calculated by using 3 doses. One dose is tested in at least 6 rats (Litchfield \& Wilcoxon I test). ${ }^{{ }^{a}}$ criterion $\geq 6$ s. ${ }^{b}$ criterion $\geq 60 \mathrm{~s}$. ${ }^{\mathrm{C}}$ criterion $\geq 30 \mathrm{~s}$.

${ }^{\star}$ Relative potency estimates were considered statistically significant when $95 \%$ CL did not overlap 1.0 $(p<0.05$, Litchfield \& Wilcoxon II test).

When the doses of all three tested drugs were increased above their antinociceptive doses, the toxic effects appeared in a similar order (Table 1, Fig. 2). Loss of pinna reflex occurred first, followed by impairment of motor coordination and Straub tail. With further increases in doses, catalepsy, loss of corneal reflex and loss of righting reflex occurred (Table 1, Fig. 2).

The therapeutic indices for all three compounds tested (calculated as $\left.T_{D_{50}} / A_{50}\right)$ are shown in Table 2. The $A D_{50}$ values for $F, C$, and $T$ are significantly lower $(p<0.05)$ than their $\mathrm{TD}_{50}$ values (Table 2). Within each effect, there are no significant differences $(p>0.05)$ between TIs for F, C and T (Table 2).

Time course of the antinociceptive and toxic effects obtained with equiantinociceptive doses $\left(4 \times E D_{50}, 8 \times E D_{50}\right.$ and $\left.15 \times E D_{50}\right)$ of $F, C$ and $T$ is presented in Fig. 3. By using equi-antinociceptive doses $\left(4 \times E D_{50}\right.$ and $\left.8 x D_{50}\right), C$ and $T$ produced significantly shorter duration of antinociception than $\mathrm{F}(p<0.01$; Mann-Whitney Utest). There is no difference in the duration of analgesia between $C$ and T. Also, $C$ and $T$ exhibited faster onset of analgesia in comparison with $F$. After i. p. injection of $4 \times A D_{50}$ of $C, T$, and $F$, analgesia peaked at 5,5 and $15 \mathrm{~min}$, respectively (Figs. 3 $A$ and $B$ ).

At doses $15 \times A D_{50}, C$ and $T$ produced significantly $(p<0.05$ or $p<0.01$; Mann-Whitney U-test) shorter duration of loss of pinna reflex, impairment of motor coordination, Straub tail, catalepsy, loss of corneal reflex, and loss of righting reflex, than $\mathrm{F}$ (Figs. $3 \mathrm{C}-\mathrm{H}$, Table 2). There is no difference in the duration of toxic effects between $\mathrm{C}$ and $\mathrm{T}$. In the majority of the effects observed, $\mathrm{C}$ and $\mathrm{T}$ achieved peak effect faster (at the first time point measurement, ie $5 \mathrm{~min}$ ) than $\mathrm{F}$ (at the second time point measurement, ie $20 \mathrm{~min}$ ) (Figs. 3C-H). 
Table 2. Therapeutic indices (TI) with 95\% confidence limits (95\% CL) and duration of toxic effects (loss of pinna reflex, motor impairement, Straub tail, catalepsy, loss of corneal reflex, loss of righting reflex) for fentanyl, ( \pm )-cis-3-carbomethoxy fentanyl and $( \pm)$-trans-3-carbomethoxy fentanyl in rats

\begin{tabular}{|c|c|c|c|c|c|c|}
\hline \multirow{2}{*}{$\begin{array}{l}\text { Drug tested } \\
\text { Effects }\end{array}$} & \multicolumn{2}{|c|}{ Fentanyl } & \multicolumn{2}{|c|}{$\begin{array}{c}( \pm) \text {-cis-3- } \\
\text { Carbomethoxy } \\
\text { fentanyl } \\
\end{array}$} & \multicolumn{2}{|c|}{$\begin{array}{l}( \pm) \text {-trans-3- } \\
\text { Carbomethoxy } \\
\text { fentanyl }\end{array}$} \\
\hline & $\begin{array}{c}\text { Therapeutic } \\
\text { index } \\
(95 \% \mathrm{CL}) \\
\end{array}$ & $\begin{array}{l}\text { Duration } \\
{(\text { (min })^{a}}^{a}\end{array}$ & \begin{tabular}{|c|}
$\begin{array}{c}\text { Therapeutic } \\
\text { index } \\
(95 \% \mathrm{CL})\end{array}$ \\
\end{tabular} & $\begin{array}{l}\text { Duration } \\
(\min )^{a}\end{array}$ & $\begin{array}{c}\text { Therapeutic } \\
\text { index } \\
(95 \% \mathrm{CL}) \\
\end{array}$ & $\begin{array}{l}\text { Duration } \\
\text { (min) }^{a}\end{array}$ \\
\hline Loss of pinna $r$. & $\begin{array}{c}2.56 * \\
(1.71-3.83) \\
\end{array}$ & 120 & $\begin{array}{c}2.53^{\star} \\
(1.73-3.70) \\
\end{array}$ & $60^{+}$ & $\begin{array}{c}3.68^{*} \\
(2.32-5.83) \\
\end{array}$ & $40^{+}$ \\
\hline Motor impair. & $\begin{array}{c}3.61^{\star} \\
(2.07-6.31) \\
\end{array}$ & 90 & $\begin{array}{c}4.12^{\star} \\
(2.23-7.65) \\
\end{array}$ & $40^{+}$ & $\begin{array}{c}5.27^{\star} \\
(3.31-8.37) \\
\end{array}$ & $40^{+}$ \\
\hline Straub tail & $\begin{array}{c}4.33^{\star} \\
(2.62-7.15) \\
\end{array}$ & 60 & $\begin{array}{c}5.20^{\star} \\
(2.94-9.20) \\
\end{array}$ & $20^{+}$ & \begin{tabular}{|c|}
$6.13^{\star}$ \\
$(3.69-10.16)$ \\
\end{tabular} & $40^{+}$ \\
\hline Catalepsy & $\begin{array}{c}6.47^{\star} \\
(4.34-9.63) \\
\end{array}$ & 60 & $\begin{array}{c}7.87^{\star} \\
(4.54-13.64) \\
\end{array}$ & $20^{+}$ & $\begin{array}{c}9.16^{\star} \\
(5.44-15.41) \\
\end{array}$ & 20 \\
\hline Loss of corneal r. & $\begin{array}{c}7.26^{\star} \\
(4.55-11.57) \\
\end{array}$ & 60 & $\begin{array}{c}8.65^{\star} \\
(5.79-12.93) \\
\end{array}$ & $40^{+}$ & $\begin{array}{c}9.18^{*} \\
(5.45-15.46) \\
\end{array}$ & $20^{+}$ \\
\hline Loss of righting $r$. & $\begin{array}{c}8.54^{*} \\
(5.60-13.02)\end{array}$ & 60 & $\begin{array}{c}10.67^{\star} \\
(7.27-15.65)\end{array}$ & $20^{+}$ & $\begin{array}{c}11.07^{\star} \\
(6.51-18.82)\end{array}$ & $5^{+}$ \\
\hline
\end{tabular}

Therapeutic index $(\mathrm{TI})$ is calculated as $\mathrm{TD}_{50} / \mathrm{AD}_{50}$ potency ratio for each drug ${ }^{*} p<0.05$, Litchfield \& Wilcoxon II test. If $95 \%$ CL for a TI fails to include 1.0 , then $T D_{50}$ and $A D_{50}$ are significantly different. aDuration of action after i.p. injection of equi-analgesic doses of $15 \times \mathrm{AD}_{50}$ by using a criteria $>50 \%$ of rats responding ${ }^{+} p<0.05$ indicates a significant shorter duration of action of fentanyl analog in comparison to fentanyl (Mann-Whitney U-test)

Naloxon hydrochloride (1 mg/kg; sc) given 10 min before ip injection of $8 \times \mathrm{ED}_{50}$ and $15 \mathrm{xED}_{50}$ of $\mathrm{F}, \mathrm{C}$ and $\mathrm{T}$ abolished antinociceptive and toxic effects (not shown).

Ip injection of saline $(0.2 \mathrm{~mL} / \mathrm{kg})$ had no effect on the animal's behavior, as well as tail immersion latency $(p>0.05)$; the latencies before and after saline injection were found to be $2.32 \pm 0.32$ and $2.40 \pm 0.25 \mathrm{~s}$, respectively $(n=8)$ (not shown).
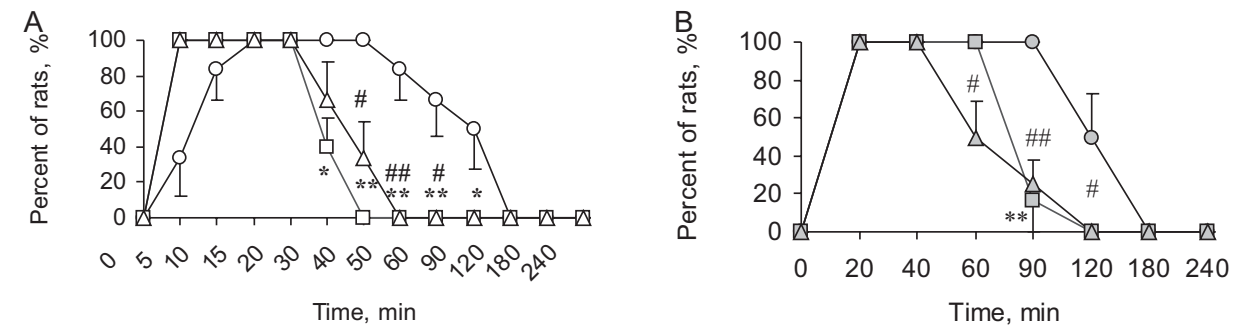

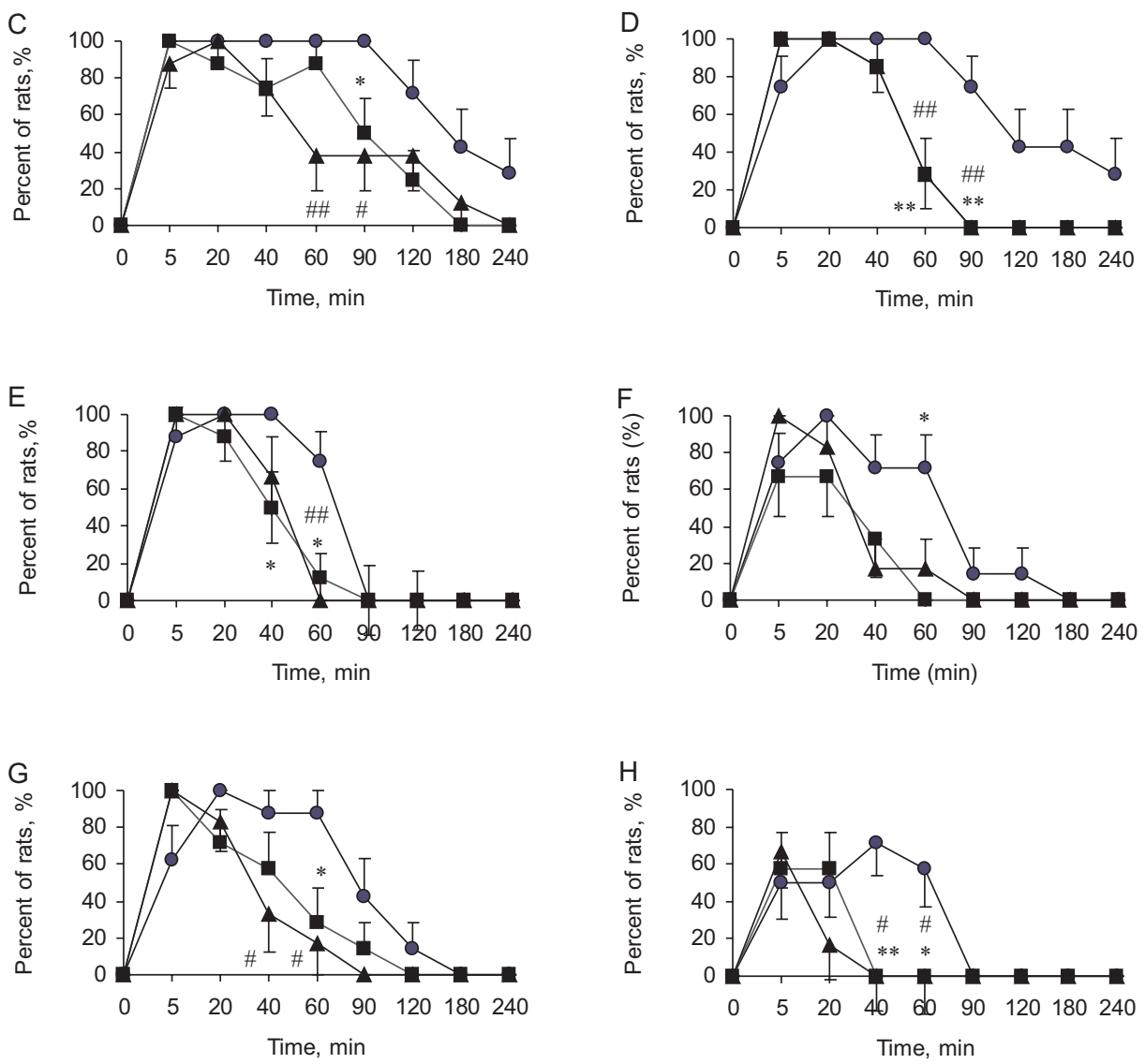

Figure 3. Time-effect curve for the antinociceptive and toxic effects of fentanyl (circle), $( \pm)$ cis-3-carbomethoxy fentanyl (quadrant) and ( \pm )-trans-3-carbomethoxy fentanyl (triangle) in rats. The incidence of antinociception (A and B), loss of pinna reflex (C), impairment of motor coordination (D), Straub tail $(E)$, catalepsy $(F)$, loss of corneal reflex $(G)$, and loss of righting reflex $(H)$ are plotted as a function of time after i.p. injection of $4 \times A D_{50}$ (white symbols), $8 \times A D_{50}$ (gray symbols) and $15 \times A D_{50}$ (black symbols) for of fentanyl, ( \pm )-cis-3-carbomethoxy fentanyl and ( \pm )-trans-3carbomethoxy fentanyl. Each dose was tested by using 6-8 rats. Each point represents the percentage of rats $\pm S$.E. that respond to the treatment. ${ }^{*} p<0.05$ and ${ }^{* *} p<0.01$ indicate a significant difference of the responses of $( \pm)$-cis-3carbomethoxy fentanyl in comparison to fentanyl (Mann-Whitney $-U$ test). ${ }^{\#} p<0.05$ and ${ }^{\# \#} p<0.01$ indicate a significant difference of the responses of $( \pm)$-trans-3carbomethoxy fentanyl in comparison to fentanyl (Mann-Whitney $-U$ test) 


\section{DISCUSSION}

In the present experiments all three compounds tested: fentanyl $(F),( \pm)$ cis 3-carbomethoxy fentanyl (C) and ( \pm )trans 3-carbomethoxy fentanyl (T), produced a dose-dependent increase in antinociception and morphine-like effects, such as loss of the pinna reflex, Straub tail, impairment of motor coordination, catalepsy, loss of corneal reflex and loss of righting reflex. This finding is in agreement with previous reports on actions of fentanyl in rats (Meert et al., 1988; Ivanović et al., 1995; Vučković et al., 1998; Vučković et al., 2000). C and T are less potent (2.4-3.1 and 8.4-12.3 times, respectively) than fentanyl $(F)$ in producing both the antinociception and neurotoxicity. The antinociceptive and toxic effects of $\mathrm{F}, \mathrm{C}$ and $\mathrm{T}$ were abolished by pretreatment with naloxone, which is a nonselective antagonist of opioid receptors, indicating that toxic effects are mediated by opioid receptors. It was revealed that F, C and T exhibited similar relative potencies in producing all tested effects. If a series of related agonists exhibits identical relative potencies in producing distinct effects, it is likely that these effects are mediated by similar or identical receptor molecules (Bourne and Zastrow, 2007). In the case of F, C and T, they are most probably of the $\mu$ type. This is consistent with previous reports that $\mu$ opioid receptors are involved in the mechanisms of opioid induced antinociception, Straub tail, muscle rigidity, catalepsy and other morphine-like behavioural effects in rats (Negri et al., 1992; Nath et al., 1994; Chen et al., 1996; Piepponen et al., 1997).

Most of the currently available opioid analgesics exert their analgesic and adverse effects primarily through the opioid $\mu$ receptors. However, individual strong opioids may interact, at least in part, with different opioid receptor subpopulations or modulate $\mu$ opioid receptor signaling in different ways (Pasternak, 2004; Lee et al., 2007), that may improve tolerability (Ananthan, 2006; Smith, 2008; Spetea et al., 2010).

There are no significant differences between therapeutic indices for F, C and T, which means that these compounds are equally tolerable in regard to the observed neurotoxic effects, and the difference between them is in the potency and the time course of action.

By using equi-antinociceptive doses, $\mathrm{C}$ and $\mathrm{T}$ produced significantly shorter duration of both, antinociception and neurotoxicity, than F. Also, there is no difference in the duration of effects between $\mathrm{C}$ and $\mathrm{T}$. One of the possible explanation for the shorter duration of action of 3-carbomethoxy fentanyl in comparison with fentanyl might be the susceptibility of the carbomethoxy group to rapid hydrolysis by non-specific esterases (Feldman et al., 1991). It is possible, also that the introduction of 3-carbomethoxy group in the piperidine ring affects duration of action by altering physicochemical properties (Scholz et al., 1996).

\section{SUMMARY}

In summary, $( \pm)$ cis 3-carbomethoxy fentanyl and ( \pm )trans 3-carbomethoxy fentanyl are less potent (2.4-3.1 and 8.4-12.3 times, respectively) than fentanyl in producing both antinociception and neurotoxicity in rats. All three compounds are 
equally tolerable and safe drugs in respect to neurotoxic effects. Also, F, C and T exhibited similar relative potencies in producing all evaluated effects, and the structure-activity relationship on neurotoxic effects of fentanyl analogs obtained by introducing carbomethoxy group in the position 3 of the piperidine ring, parallels the structure-activity relationship on antinociception. All of these taken together, might suggest that similar receptors are involved in producing both antinociceptive and neurotoxic effects of $\mathrm{F}, \mathrm{C}$ and $\mathrm{T}$, most probably of $\mu$ type.

Animal testing presented in this paper consists of procedures which can be performed easily and in parallel manner providing several useful pharmacological informations regarding efficacy, potency, time course of action, safety and tolerability, and also, could be indicative whether the observed drug effects are mediated by similar or different receptors. Therefore, we recommend it as a useful approach in studying the structure-activity relationship of opioid congeners.

ACKNOWLEDGEMENT:

This work was supported by Ministry of Science and Technological Development of Serbia (Grant No. 175023).

Address for correspondence:

Sonja Vučković, M.D., Ph.D.

Department of Pharmacology, Clinical Pharmacology and Toxicology

School of Medicine

Dr Subotića 1

P.O. Box 38

11129 Belgrade, Serbia

E-mail: svuckovic@mfub.bg.ac.rs; sonyav@sbb.rs

\section{REFERENCES}

1. Ananthan S, 2006, Opioid ligands with mixed mu/delta opioid receptor interactions: an emerging approach to novel analgesics, AAPSJ, 8, E118-25.

2. Benthuysen JL, Smith NT, Sanford TJ, Head N, Dec-Silver H, 1986, Physiology of alfentanil-induced rigidity, Anesthesiology, 64, 440-6.

3. Bourne H, von Zastrow M, 2007, Drug receptors \& pharmacodynamics. In: Katzung BG, editor, Basic and Clinical Pharmacology, New York: The McGraw-Hill Companies Inc, 11-33.

4. Chen SW, Maguire PA, Davies MF, Beatty MF, Loew GH, 1996, Evidence for mu1-opioid receptor involvement in fentanyl-mediated respiratory depression, Eur J Pharmacol, 312, 241-4.

5. De Vos V, 1978, Immobilisation of free-ranging wild animals using a new drug, Vet Rec, 103, 64-8.

6. Feldman PL, James MK, Brackeen MF, Bilotta JM, Schuster SV, Lahey AP et al., 1991, Design, synthesis, and pharmacological evaluation of ultrashort- to long-acting opioid analgetics, $J$ Med Chem, 34, 2202-8.

7. Geppetti P, Benemei S, 2009, Pain treatment with opioids:achieving the minimal effective and the minimal interacting dose, Clin Drug Investig, 29, Suppl 1, 3-16.

8. Ivanović M, Vučković S, Ristović Z, . Mićović I, Beleslin D, 1995, Behavioural effects of fentanyl in rats, Iugoslav Physiol Pharmacol Acta, 31,195-9.

9. Ivanović MD, Mićović IV, Vučković S, Prostran M, Todorović Z, Ivanović R et al., 2004a, The synthesis and pharmacological evaluation of ( \pm )-2,3-seco-fentanyl analogues, J Serb Chem Soc, 69, 955-68.

10. Ivanović MD, Mićović IV, Vučković S, Prostran M, Todorović Z, Kricojević VD et al. , 2004b, The synthesis and preliminary pharmacological evaluation of the racemic cis and trans 3-alkyl fentanyl analogues, J Serb Chem Soc, 69, 511-26. 
11. Janssen PAJ, Niemegeers CJE, Dony JGH, 1963, The inhibitory effect of fentanyl and other morphine-like analgesics on the warm water induced tail withdrawal reflex in rats, ArzneimittelForsch (Drug Res), 13, 502-7.

12. Klemm WR, 1989, Drug effects on active immobility responses: what they tell us about neurotransmitter systems and motor functions, Prog Neurobiol 32, 403-22.

13. Lee YS, Nyberg J, Moye S, Agnes RS, Davis P, Ma SW et al., 2007, Understanding the structural requirements of 4-anilidopiperidine analogues for biological activities at mu and delta opioid receptors, Bioorg Med Chem Lett, 17, 2161-5.

14. Meert TF, Lu HR, van Craenndonck H, Janssen PA, 1988, Comparison between epidural fentanyl, sufentanil, carfentanil, lofentanil and alfentanil in the rat: analgesia and other in vivo effects, Eur $J$ Anaesthesiol, 5, 313-21.

15. Mićović IV, Ivanović MD, Vučković S, Jovanović-Mićić D, Beleslin D, Došen-Mićović Lj et al., 1998, 3Carbomethoxy fentanyl: Synthesis, pharmacology and conformational analysis, Heterocycl Commun, 4,171-9.

16. Mićović IV, Ivanović MD, Vučković SM, Prostran MŠ, Došen-Mićović L, Kiricojević VD, 2000, The synthesis and preliminary pharmacological evaluation of 4-methyl fentanyl, Bioorg Med Chem Lett, 10, 2011-4.

17. Nath C, Gupta MB, Patnaik GK, Dhawan KN, 1994, Morphine-induced straub tail response: mediated by central mu2-opioid receptor, Eur J Pharmacol, 263, 203-5.

18. Negri L, Erspamer GF, Severini C, Potenza RL, Melchiorri P, Erspamer V, 1992, Dermorphin-related peptides from the skin of Phyllomedusa bicolor and their amidated analogs activate two mu opioid receptor subtypes that modulate antinociception and catalepsy in the rat, Proc Natl Acad Sci U S A, 89, 7203-7.

19. Pasternak GW, 2004, Multiple opiate receptors: déjà vu all over again, Neuropharmacology, 47, Suppl 1, 312-23.

20. Piepponen TP, Kivastik T, Katajamäki J, Zharkovsky A, Ahtee L, 1997, Involvement of opioid mu 1 receptors in morphine-induced conditioned place preference in rats, Pharmacol Biochem Behav, 58, 275-9.

21. Scholz J, Steinfath M, Schulz M, 1996, Clinical pharmacokinetics of alfentanil, fentanyl and sufentanil. An update, Clin Pharmacokinet, 31, 275-92.

22. Schumacher MA, Basbaum A, Way WL, 2007, Opioid analgesics \& Antagonists, In: Katzung BG, editor, Basic and Clinical Pharmacology, New York: The McGraw-Hill Companies Inc, 489-510.

23. Smith MT, 2008, Differences between and combinations of opioids re-visited. Curr Opin Anaesthesiol, 21, 596-601.

24. Spetea M, Bohotin CR, Asim MF, Stübegger K, Schmidhammer $H, 2010$, In vitro and in vivo pharmacological profile of the 5-benzyl analogue of 14-methoxymetopon, a novel mu opioid analgesic with reduced propensity to alter motor function, Eur J Pharm Sci, 41, 125-35.

25. Tallarida RJ, Murray RB, 1986, Manual of pharmacologic calculations with computer programs, New York: Springer Verlag.

26. Van Daele PG, De Bruyn MF, Boey JM, Sanczuk S, Agten JT, Janssen PA, 1976, Synthetic analgesics: $\quad \mathrm{N}$-(1-(2-arylethyl)-4-substituted 4-piperidinyl) $\quad \mathrm{N}$-arylalkanamides, Arzneimittelforschung, 26, 1521-31.

27. Vankova ME, Weinger MB, Chen DY, Bronson JB, Motis V, Koob GF, 1996, Role of central mu, delta1, and kappa-1 opioid receptors in opioid-induced muscle rigidity in the rat, Anesthesiology, 85 , 574-83.

28. Vučković S, Ivanović M, Prostran M, Todorović Z, Ristović Z, Mićović I et al., 1998, Higher environmental temperature potentiates cataleptic effect of fentanyl in rats, Jpn J Pharmacol, 78 , 523-7.

29. Vučković S, Prostran M, Ivanović M, Došen-Mićović Lj, Todorović Z, Nešić Z et al., 2009, Fentanyl analogs: structure-activity-relationship study, Curr Med Chem, 16, 2468-74.

30. Vučković S, Prostran M, Ivanović M, Ristović Z, Stojanović $R, 2000$, Antinociceptive activity of the novel fentanyl analogue iso-carfentanil in rats, Jpn J Pharmacol, 84,188-95. 
31. Yaksh TL, Noueihed RY, Durant PA, 1986, Studies of the pharmacology and pathology of intrathecally administered 4-anilinopiperidine analogues and morphine in the rat and cat, Anesthesiology, 64, 54-66.

32. Yang PK, Weinger MB, Negus SS, 1992, Elucidation of dose-effect relationships for different opiate effects using alfentanil in the spontaneously ventilating rat, Anesthesiology, 77, 153-61.

\section{ISPITIVANJE NEUROTOKSIČNOSTI ANALOGA FENTANILA KOD PACOVA}

VUČKOVIĆ SONJA, SAVIĆ VUJOVIĆ KATARINA, IVANOVIĆ M, DOŠEN-MIĆOVIĆ LJILJANA, TODOROVIĆ Z, VUČETIĆ Č, PROSTRAN M I PROSTRAN MILICA

\section{SADRŽAJ}

Cilj studije bio je da se ispita neurotoksičnost analoga fentanila: ( \pm )-cis-3karbometoksi fentanila (C) i ( \pm )-trans-3-karbometoksi fentanil (T) kod pacova. C je oko 2,4-3,1, a T oko 8,4-12,3 puta manje potentan od fentanila u izazivanju antinocicepcije i morfinu-sličnih neurotoksičnih efekata u koje spadaju: refleks ušne školjke, Straub-ov rep, poremećaj motorne koordinacije, katalepsija, gubitak kornealnog refleksa i gubitak refleksa uspravljanja. Svi ispitivani efekti su dozno-zavisni i bivaju poništeni ako se u pretretmanu primeni nalokson, neselektivni antagonist opioidnih receptora, što ukazuje da se efekti odigravaju posredstvom opioidnih receptora. Dalje, F, C i T ispoljavaju sličnu relativnu jačinu u izazivanju ispitivanih efekata, što ukazuje da su slični receptori uključeni u mehanizam antinocicepcije i neurotoksičnih efekata, i to su najverovatnije $\mu$ receptori. Kad se primenjuju ekviantinociceptivne doze, C i T izazivaju značajno kraće i antinociceptivno i neurotoksično dejstvo od F. Nisu dokazane značajne razlike u terapijskim indeksima između F, C i T, što ukazuje da su ovi lekovi jednako bezbedni i podnošljivi kad su u pitanju ispitivani neurotoksični efekti. Ispitivanje neurotoksičnosti prikazano u ovom radu može biti korisno u proučavanju odnosa između strukture i aktivnosti hemijski srodnih opioida. 